\title{
Evolutionary and prognostic implications in patient with acute coronary syndrome and dysthyroidism
}

\author{
Implicații evolutive și de prognostic la pacientul cu \\ sindrom coronarian acut și distiroidie \\ Eleonora DRĂGAN ${ }^{1,2}$, Maria Suzana GUBERNA ${ }^{1,2}$, Cătălina Liliana ANDREI ${ }^{1,2}$, \\ Crina-Julieta SINESCU ${ }^{1,2}$ \\ ${ }^{1}$ Universitatea de Medicină și Farmacie „Carol Davila“, București, România \\ ${ }^{2}$ Clinica de Cardiologie, Spitalul Clinic de Urgență „Bagdasar-Arseni“, București, România
}

\begin{abstract}
Purpose. The study aims to determine the impact of dysthyroidism on the severity and type of coronary lesion, on vascular function, as well as on the morbidity and mortality of patients with acute coronary syndrome, by finding predictive markers that can be translated into preventive measures that contribute substantially to reduce the number of newly diagnosed patients with coronary heart disease.

Methods. We introduced in the study 100 patients recently diagnosed with acute coronary syndrome, without history of ischemic heart disease or thyroid disease, hospitalized in the Cardiology Clinic of the "Bagdasar-Arseni" Emergency Clinical Hospital Bucharest, for the interventional treatment of acute coronary syndrome. The studied patients were hospitalized between November 2014 and April 2015, with regular follow-up of up to 5 years (telephone or direct interview, conducted at 6 months, 12 months, 24 months, 36 months, 48 months, 60 months), with an average period follow-up of 1006 days, evaluated clinically, bio-humorally, by echocardiography, explored with coronary angiography with the calculation of the SYNTAX score and with the performance of electrocardiogram and pulse wave. The obtained data were integrated in Excel sheets and statistically processed with the Python program.

Results. The mortality rate in the patient group was 7\% (7 deaths). Descriptively, of the deceased, 6 patients (86\%) were male, and as thyroid status 1 hyperthyroid patient (14\%), 3 hypothyroid patients $(43 \%)$ and 3 patients $(43 \%)$ normothyroid. There were 4 deaths $(8 \%)$ in the group of patients with unstable angina and 3 deaths ( $8 \%$ ) in the group of patients with myocardial infarction without ST-segment elevation. There were no deaths in the group of patients with acute myocardial infarction with ST-segment elevation. At follow-up, 41 patients (41\%) were readmitted. Re-hospitalization was influenced by elevated values of mean blood pressure, diastolic blood pressure and C-reactive protein, unicoronary atherosclerotic disease and unstable angina at admission. At follow-up, the development of noncardiac events was noted in the evolution of patients, diabetes mellitus occurring in the majority, in almost a quarter of patients (22 patients, respectively 24\% developed diabetes over time), 34\% (19 patients) in euthyroidism and 8\% (3 patients) dysthyroidism.

Discussions. Predictive factors for the readmission of the patient with acute coronary syndrome are highlighted the following: increased level of C-reactive protein $(p=0.017)$, tricoronary vascular damage
\end{abstract}


$(p=0.01)$, diastolic blood pressure greater than $80 \mathrm{mmHg}(p=0.025)$, and euthyroid status $(p=0.04)$. The probability of death for the patient with acute coronary syndrome rises to $66 \%$ in the presence of severe systolic dysfunction of the left ventricle $(p=0.006)$, and to $61 \%$ in the case of elevated values of hs troponin I $(p=0.008)$. In our study, the presence of dysthyroidism in the patient with acute coronary syndrome has a protective role in the development of diabetes in the first 5 years $(p=0.025)$.

Conclusion. Dysthyroidism is associated with increased morbidity and mortality from cardiovascular disease.

Keywords: acute coronary syndrome, thyroid dysfunction, SYNTAX score, outcome

\section{REZUMAT}

Obiective. Studiul își propune să determine impactul distiroidiei asupra severității și tipului de leziune coronariană, asupra funcției vasculare, precum și asupra morbidității și mortalității pacienților cu sindrom coronarian acut, prin găsirea unor markeri predictivi care să poată fi translatați în măsuri preventive care să contribuie substanțial la reducerea numărului pacienților cu boală coronariană nou diagnosticați.

Material și metode. Am introdus în studiu 100 de pacienți recent diagnosticați cu sindrom coronarian acut, fără istoric de boală cardiacă ischemică sau de boală tiroidiană, internați în Clinica de Cardiologie a Spitalului Clinic de Urgență Bagdasar-Arseni București, pentru tratamentul intervențional al sindromului coronarian acut. Pacienții studiați au fost internați în perioada noiembrie 2014 - aprilie 2015, cu urmărire periodică până la 5 ani (interviu telefonic sau direct, realizat la 6 luni, 12 luni, 24 luni, 36 luni, 48 luni, 60 luni), cu perioada medie de urmărire de 1006 zile, evaluați clinic, bio-umoral, prin ecocardiografie, explorați coronarografic cu calcularea scorului SYNTAX și cu efectuare de electrocardiogramă și undă de puls. Datele obținute au fost integrate în fișe Excel și prelucrate statistic cu programul Python.

Rezultate. Rata de mortalitate in lotul de pacienți a fost de 7\% (7 decese). Descriptiv, dintre cei decedați, 6 pacienți (86\%) au fost de sex masculin, iar ca status tiroidian 1 pacient hipertiroidian (14\%), 3 pacienți hipotirodieni (43\%) și 3 pacienți (43\%) normotiroidieni. S-au innregistrat 4 decese (8\%) în grupul de pacienți cu angină instabilă și 3 decese (8\%) în grupul de pacienți cu infarct miocardic fără supradenivelare de segment ST. Nu s-a înregistrat niciun deces în grupul pacienților prezentați cu infarct miocardic acut cu supradenivelare de segment ST. La follow-up, 41 de pacienți $(41 \%)$ s-au reinternat. Reinternarea a fost influențată de valorile crescute ale tensiunii arteriale medii, tensiunii arteriale diastolice și proteinei $C$ reactive, de boala aterosclerotică tricoronaraină și prezența anginei instabile la internare. La follow-up, în evoluția pacienților a fost notată dezvoltarea unor evenimente noncardiace, diabetul zaharat apărând majoritar, la aproape un sfert dintre pacienți (22 de pacienți, respectiv $24 \%$ au dezvoltat în timp diabet zaharat), 34\% (19 pacienți) în eutiroidie și $8 \%$ (3 pacienți) cu distiroidie.

Discuții. Factori predictori pentru reinternarea pacientului cu sindrom coronarian acut sunt evidențiați următorii: nivelul crescut al proteinei $C$ reactive $(p=0,017)$, afectarea vasculară tricoronariană $(p=0,01)$, tensiunea arterială diastolică mai mare de $80 \mathrm{mmHg}(p=0,025)$, precum și statusul eutiroidian $(p=0,04)$. Probabilitatea de deces la pacientul cu sindrom coronarian acut se ridică la $66 \%$ in prezența disfuncției sistolice severe de ventricul stâng $(p=0,006)$, și la $61 \%$ in cazul valorilor crescute de hs troponină $I(p=0,008)$. In studiul nostru, prezența distiroidiei la pacientul cu sindrom coronarian acut are un rol protector în dezvoltarea diabetului zaharat în primii 5 ani $(p=0,025)$.

Concluzii. Distiroidia este asociată cu creșterea morbidității și mortalității prin boala cardiovasculară.

Cuvinte cheie: sindrom coronarian acut, disfuncție tiroidiană, scor SYNTAX, evoluție

\section{INTRODUCERE}

Tiroida și inima își încep interacțiunea încă din timpul vieții embrionare. În timpul ontogenezei, cele două organe migrează împreună. Modificările funcției cardiovasculare apărute în diverse tipuri de boală tiroidiană și complicațiile cardiovasculare ale distiroidiilor demonstrează interacțiunea fiziologică strânsă dintre cele două organe (1).
În ciuda progreselor înregistrate în farmacoterapie și procedurile de reperfuzie miocardică, mortalitatea pe termen scurt și lung a pacienților care suferă de sindrom coronarian acut (SCA) rămâne semnificativă. S-a perceput de multă vreme că modificarea concentrației plasmatice a hormonilor tiroidieni (HT) este legată de boala acută cardiacă (2).

Hormonii tiroidieni - tiroxina (T4), izolată în 1915 de Kendall, și triiodotironina (T3), descoperită în 1952 de 
Gross și Pitt-Rivers (3-5) - au rol în aproape toate acțiunile metabolice din organism (3). Prin urmare, modificări ale funcțiilor hormonilor pot duce la mai multe tulburări. Hormonul stimulator al tiroidei (TSH) activează sinteza tiroxinei (T4) și triiodotironinei (T3) în glanda tiroidă. Funcția hormonilor tiroidieni are un impact mare asupra fiziologiei cardiovasculare, incluzând ritmul cardiac, tensiunea arterială, debitul cardiac, rezistența vasculară sistemică și contractilitatea miocardului. Hipotiroidismul subclinic a fost asociat cu o incidență crescută a aterosclerozei și a infarctului miocardic în mai multe studii. Studii recente din Marea Britanie au raportat, de asemenea, că tratarea pacientului cu hipotiroidism subclinic cu înlocuire a tiroxinei poate reduce incidența evenimentelor de boală cardiacă ischemică și a mortalității cardiovasculare (2).

Scorul SYNTAX, derivat din clasificări anterioare (American Heart Association, Studiul Terapiilor de Revascularizare Arterială, scorul Leaman, ICPS - Colegiul Interamerican al medicilor și chirurgilor), este folosit pentru determinarea complexității bolii coronariene. Scorul însumează punctele alocate fiecărei leziuni din circulația coronariană; se folosește un algoritm de calcul și rezultă valoarea scorului, folosită ca indicator de evenimente cardiovasculare (scorul mare este asociat cu mortalitate cardiacă crescută și evenimente cardiace majore) (6).

\section{OBIECTIVE}

Am analizat impactul distiroidiei pe severitatea și tipul leziunilor coronariene și asupra funcției vasculare și, nu în ultimul rând, răsunetul biologic general, obiectivând modificarea leziunilor coronariene, cu implicații în evoluția pacientului. Prin urmare, am studiat impactul disfuncției tiroidiene asupra morbidității și mortalității acestor pacienți, incluzând și o analiză a reinternării pacienților.

Important, studiul nostru și-a propus, de asemenea, să ofere informații despre predictorii statusului de reinternare și despre factorii contributori la deces, informații care pot fi utile pentru clinicienii care gestionează pacienții cu sindrom coronarian acut.

\section{MATERIAL ŞI METODE}

Am conceput acest studiu bazat pe înrolarea unor subiecți recent diagnosticați cu sindrom coronarian acut. Este un studiu realizat prospectiv, longitudinal, care a inclus un eșantion de 100 pacienți prezentați la Spitalul Clinic de Urgență „Bagdasar-Arseni“ București, și care au primit diagnosticul de sindrom coronarian acut. Pacienții studiați au fost internați în perioada noiembrie 2014 - aprilie 2015, cu urmărire periodică până la 5 ani (interviu telefonic sau direct, realizat la 6 luni,
12 luni, la 24 luni, 36 luni, 48 luni, 60 luni) - perioadă medie de urmărire de 1006 zile. Studiul este analitic observational de tip cohortă - fiind incluși pacienți consecutivi care prezintă criteriile de includere. Pacienții au fost internați în Clinica noastră de Cardiologie pentru tratamentul intervențional al sindromului coronarian acut. Pacienții au fost prezentați direct sau transferați de la alte spitale din București sau din județele limitrofe, internați și evaluați în Clinica de Cardiologie SCUBA. Pacienții nu aveau istoric de boală cardiacă ischemică sau de boală tiroidiană.

Pacienții au fost incluși pe baza registrului de protocol operator al Laboratorului de Angiografie, cei care nu au fost supuși la o evaluare invazivă nefiind selectați.

Fiecărui pacient i s-au explicat metodologia studiului și beneficiile tratamentului sindromului coronarian acut și s-a obținut un consimțământ semnat olograf de la fiecare pacient care a fost de acord să intre în studiu. Toate procedurile care privesc subiecții umani au fost efectuate în conformitate cu liniile directoare stabilite în Declarația de la Helsinki (octombrie 2008).

$\mathrm{Ne}$-am propus realizarea acest studiu ca urmare a mai multor aspecte: există un număr mare de pacienți nou diagnosticați cu sindrom coronarian acut și, astfel, înrolarea în studiu nu a pus probleme deosebite; explorările leziunilor coronariene și determinarea nivelurilor de hormoni tiroidieni implică dotare tehnică accesibilă (laborator de angiografie în care își desfășoară activitatea medici cu competență în cardiologie intervențională, laborator care efectuează analize de rutină și analize hormonale), unități disponibile în cadrul Clinicii de Cardiologie a Spitalului Clinic de Urgență „BagdasarArseni“.

Criteriile de includere sunt reprezentate de: sindrom coronarian acut (angina instabilă / infarct miocardic fără supradenivelare de segment ST / infarct miocardic cu supradenivelare de segment ST) - primul episod - evaluat angiografic, definit prin prezența anamnezei sugestive plus/minus markeri de necroză miocardică cu eventuală evolutivitate, și simptome clinice compatibile cu ischemia miocardică, și/sau cu aspect ecografic corespondent sau traseu ECG, cu vârsta peste 18 ani și care au semnat consimțământul informat.

Criteriile de excludere sunt: boala tiroidiană preexistentă, fibrilația atrială, diabetul zaharat/ toleranța alterată la glucoză, boala cardiacă ischemică documentată anterior, cardiomiopatia dilatativă, tromboembolia pulmonară, infecții, neoplazii sau condiții care afectează speranța de viață, boala renală cronică, boli valvulare cu regurgitare peste gradul II sau stenoze, accident vascular cerebral în antecedente, boala arterială periferică, tratamentul cu corticosteroizi, amiodaronă, litiu, pacienți la care s-a administrat substanță de contrast iodată în ultimele două săptămâni, pacienți cu cooperare limitată sau capacitate legală limitată. 
Criteriile de includere și excludere nu au căutat decât să determine obținerea unui lot omogen de pacienți.

Evaluarea inițială a inclus anamneza cu privire la istoricul medical, datele demografice, factorii de risc și stilul de viață, antecedentele heredocolaterale (în special de boală cardiacă ischemică), examinarea fizică, tratamentele cronice curente. După evaluarea inițială, toți subiecții au fost supuși ecocardiografiei, au efectuat electrocardiografie și analiza undei de puls, și li s-a recoltat un set complet de analize de sânge. Pentru recoltarea de sânge, pacienții au fost instruți să aibă un interval de post de 12 ore peste noapte.

Datele demografice ale pacienților și antecedentele medicale (am acceptat doar prezența hipertensiunii arteriale și fumatul, din dorința de a avea un lot cât mai omogen de pacienți) au fost înregistrate cu ajutorul unui chestionar standard, constituind fișa pacientului.

Pacienții au fost reevaluați prin interviuri telefonice (timp mediu de urmărire 1006 zile) obținându-se date despre evoluția clinică, reinternare, evenimente cardiovasculare adverse, apariția altor patologii, tratament și status prezent. Informațiile la distanță au fost obținute în mod direct, indirect sau prin baza de date națională a Casei Naționale de Asigurări de Sănătate.

Datele au fost introduse în program Excel și prelucrate statistic cu programul Python.

\section{REZULTATE}

Vârsta medie a pacienților a fost 61,5 ani, cu o deviație standard de 11,5 ani (minimum 24 ani, maximum 85 ani). Repartiția pe sexe a pacienților din lot este următoarea: 35 femei (35\%) și 65 bărbați (65\%). Majoritatea pacienților provin din mediul urban (66 de pacienți, 66\%).

Dintre toți pacienții, 44 (44\%) sunt distiroidieni, restul de 56 (56\%) de pacienți fiind eutiroidieni. Dintre pacienții cu distiroidie, 10 pacienți (23\%) prezintă hipertiroidie, iar 34 pacienți (77\%) prezintă hipotiroidie. Dintre pacienții cu hipotiroidie, 20 (59\%) au hipotiroidie subclinică.

Angina instabilă a reprezentat tipul de sindrom coronarian acut majoritar la pacienții cu hipertiroidie (7 pacienți, 70\%), pe când infarctul miocardic acut fără supradenivelare de segment ST a reprezentat tipul majoritar de prezentare la pacienții cu hipotiroidie (19 pacienți, 56\%).

Gradul afectării coronariene cuantificat prin scorul SYNTAX în urma explorării coronarografice arată următoarea distribuție: 19 pacienți (19\%) au afectare coronariană nesemnificativă, 31 pacienți (31\%) prezintă afectare unicoronariană, 29 de pacienți (29\%) au afectare bicoronariană, pe când 21 de pacienți (21\%) sunt tricoronarieni.
La explorarea coronarografică pacienții cu hipertiroidism au prezentat afectare unicoronariană (5 pacienți, $50 \%$ ), bicoronariană (4 pacienți, 40\%) și tricoronariană (1 pacient, 10\%); pacienții cu hipotiroidism au avut afectare coronariană după cum urmează: 10 pacienți (29\%) - bicoronariană, 10 pacienți $(29 \%)$ - afectare nesemnificativă, 8 pacienți (24\%) - tricoronariană și 6 pacienți $(18 \%)$ - unicoronariană.

Inițial, am evaluat dacă există diferențe semnificative între media scorului SYNTAX pentru cei cu distiroidie și media scorului SYNTAX pentru cei cu eutiroidie. Dacă ar exista o diferență semnificativă între ele, ar fi un prim indicator al faptului că sindromul coronarian acut se manifestă diferit în cazul celor cu distiroidie. O diferență semnificativă între medii se referă la situația când, în urma analizei pe eșantion, putem trage concluzia cu o anumită probabilitate (mare) că, dacă am compara mediile scorului SYNTAX ale tuturor pacienților, chiar și acelea ar fi diferite. Spre exemplu, în eșantionul nostru, media scorului SYNTAX pentru cei cu distiroidie este de 24,94, iar pentru cei fără distiroidie (cu eutiroidie) este 22,83. Întrebarea este dacă media SYNTAX a tuturor pacienților cu distiroidie diferă de media SYNTAX a tuturor pacienților eutiroidieni. Se observă o ușoară diferență în figura 1.

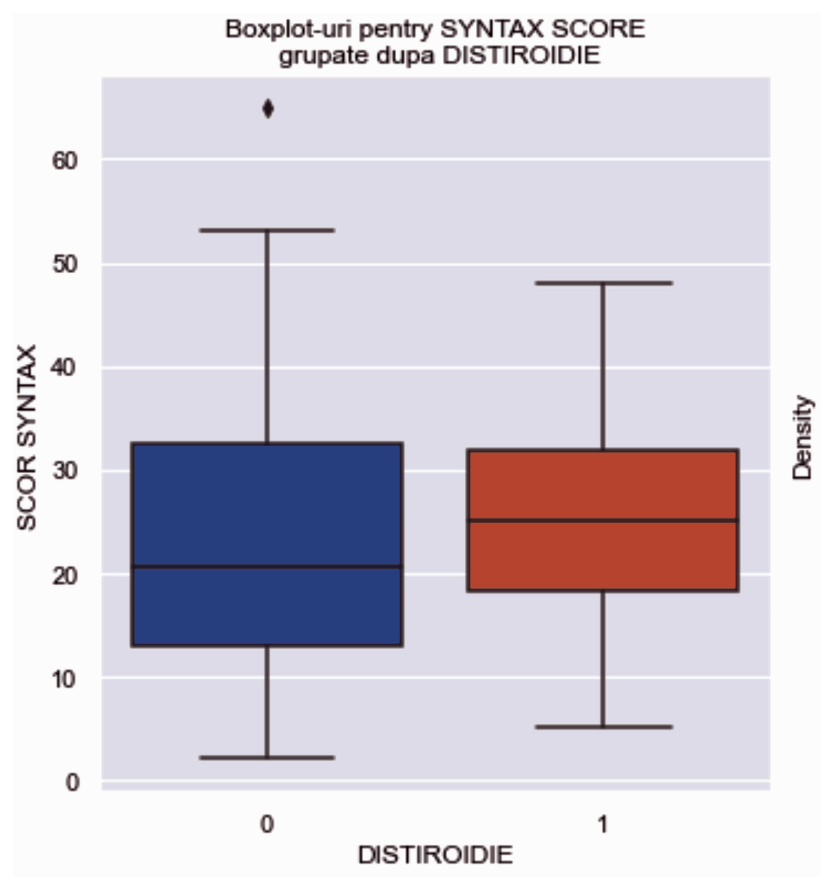

FIGURA 1. Scorul SYNTAX la pacienții cu eutiroidie și la pacienții cu distiroidie

În ceea ce privește distiroidia și mortalitatea la 5 ani, fiind vorba de o problemă statistică similară cu cea de la punctul anterior, modul în care se analizează problema este similar. Ceea ce se cercetează în eșantion este de a vedea dacă este vreo diferență între proporțiile de decedați pentru cele două grupe: cu distiroidie și 
Bar Chart

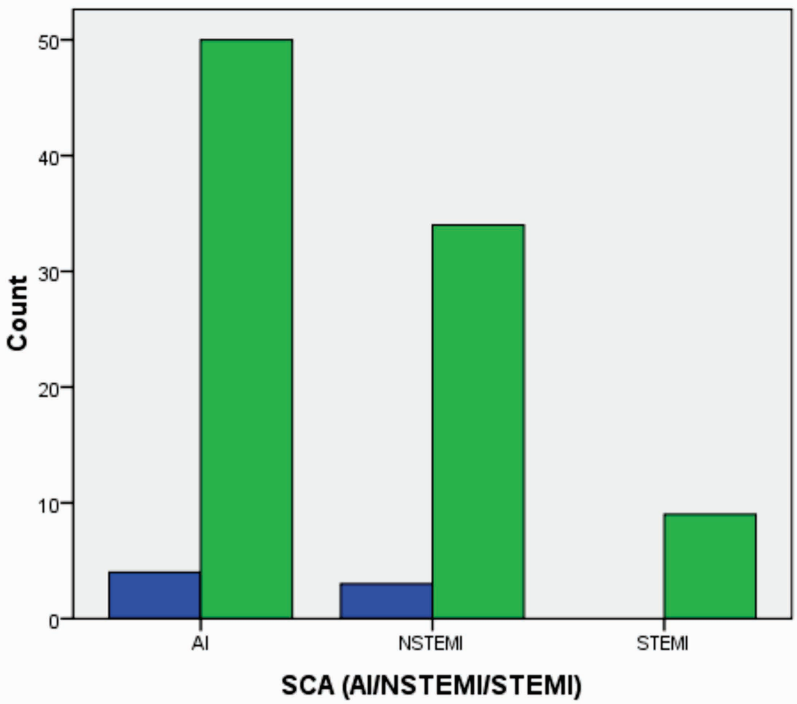

DECEDAT (DA/NU)

$\square \mathrm{DA}$
$\square \mathrm{NU}$

FIGURA 2. Rata de mortalitate la diferite tipuri de sindrom coronarian acut

fără distiroidie. Rata de deces în lotul de pacienți studiați a fost de $7 \%$ (7 pacienți au decedat) - 1 (14\%) pacient cu status hipertiroidian, 3 (43\%) pacienți eutiroidieni și 3 (43\%) pacienți cu status hipotiroidian. Rata de deces este aceeași în lotul de pacienți internați cu angină instabilă (4 pacienți; 8\%) și în lotul de pacienți internați cu infarct miocardic fără supredenivelare de segment ST (3 pacienți; 8\%). Nu s-a înregistrat niciun deces în grupul pacienților prezentați cu infarct miocardic acut cu supradenivelare de segment ST (figura 2).

Dintre pacienții supraviețuitori, 41 (44\%) au avut nevoie de reinternare la un anumit moment. 33 pacienți $(80,48 \%)$ au prezentat evenimente cardiovasculare (NSTEMI, angină instabilă, sincopă). Au fost notate în evoluția pacienților la follow-up și apariția unor evenimente noncardiace: boala vasculară periferică, accidentul vascular cerebral, boala renală, boala digestivă, diabetul zaharat.

Pentru această analiză, am luat în considerare cele două variabile ale pacienților: „distiroidie“ și „alte evenimente postexternare" (figura 3). Dintre cei 100 de pacienți, s-au eliminat cei 7 pacienți care au decedat și încă unul pentru care nu am avut informația disponibilă.

Se cercetează dacă există vreo diferență semnificativă între evenimentele extracardiace ulterioare și distiroidie. $O$ diferență semnificativă apare la pacienții cu diabet zaharat. Diabetul zaharat a apărut la 22 pacienți (24\%) urmăriți la follow-up, dintre care 19 pacienți (34\%) sunt în grupul de eutiroidieni, și 3 pacienți (8\%) sunt în grupul cu distiroidie. Ca interpretare, la valoarea $p<0,05$, rezultă că este o legătură semnificativă statistic între distiroidie și diabet zaharat, iar aceasta poate fi cuantificată prin estimatorul -1,7314. Aplicând un test chi-square pentru a vedea dacă sunt diferențe semnificative și având în vedere că testul folosește puține observații (pacienți) și mai multe tipuri de evenimente postexternare care sunt în procente similare, avem nevoie de o investigație mai detaliată a legăturii între distiroidie și evenimentul DZ (diabet zaharat). Pentru acest lucru am aplicat o regresie logistică, vrând să explicăm apariția DZ în evoluție atunci când apare distiroidia. Deci probabilitatea de apariție a DZ la un pacient scade de la 33,9\% la 8,3\% atunci când pacientul are distiroidie. Conform rezultatelor pe eșantionul folosit putem spune ca pacienții cu distiroidie au probabilitatea cu aproximativ $25 \%$ mai mică de a dezvolta diabet zaharat în viitor.

Pentru a identifica predictori buni ce estimează probabilitatea de reinternare, s-au luat pentru investigații amănunțite cei din matricea de corelație care aveau o corelație cel puțin foarte mică. Variabilele investigate sunt următoarele: TAM (tensiunea arterială medie) $>100 \mathrm{mmHg}$, tensiunea arterială diastolică $>80 \mathrm{mmHg}$, proteina $\mathrm{C}$ reactivă $>3 \mathrm{mg} / \mathrm{dl}$, toleranța la efort limitată, afectarea tricoronariană, apariția anginei instabile ca eveniment post-externare de natură cardiacă. Investigațiile amănunțite au constat în aplicarea de regresii logistice în diferite combinații. Este de remarcat faptul că aceste variabile nu funcționează bine împreună pentru estimarea probabilității ci trebuie folosite individual. Acest lucru se datorează, probabil, setului mic de date, fiind dificilă de estimat contribuția colectivă sau a diferitelor combinații de variabile. Luate individual, se pare că unele dintre ele au o anumită contribuție. Rezultatele pentru variabilele cu contribuții semnificative sunt descrise în tabelul 1. 


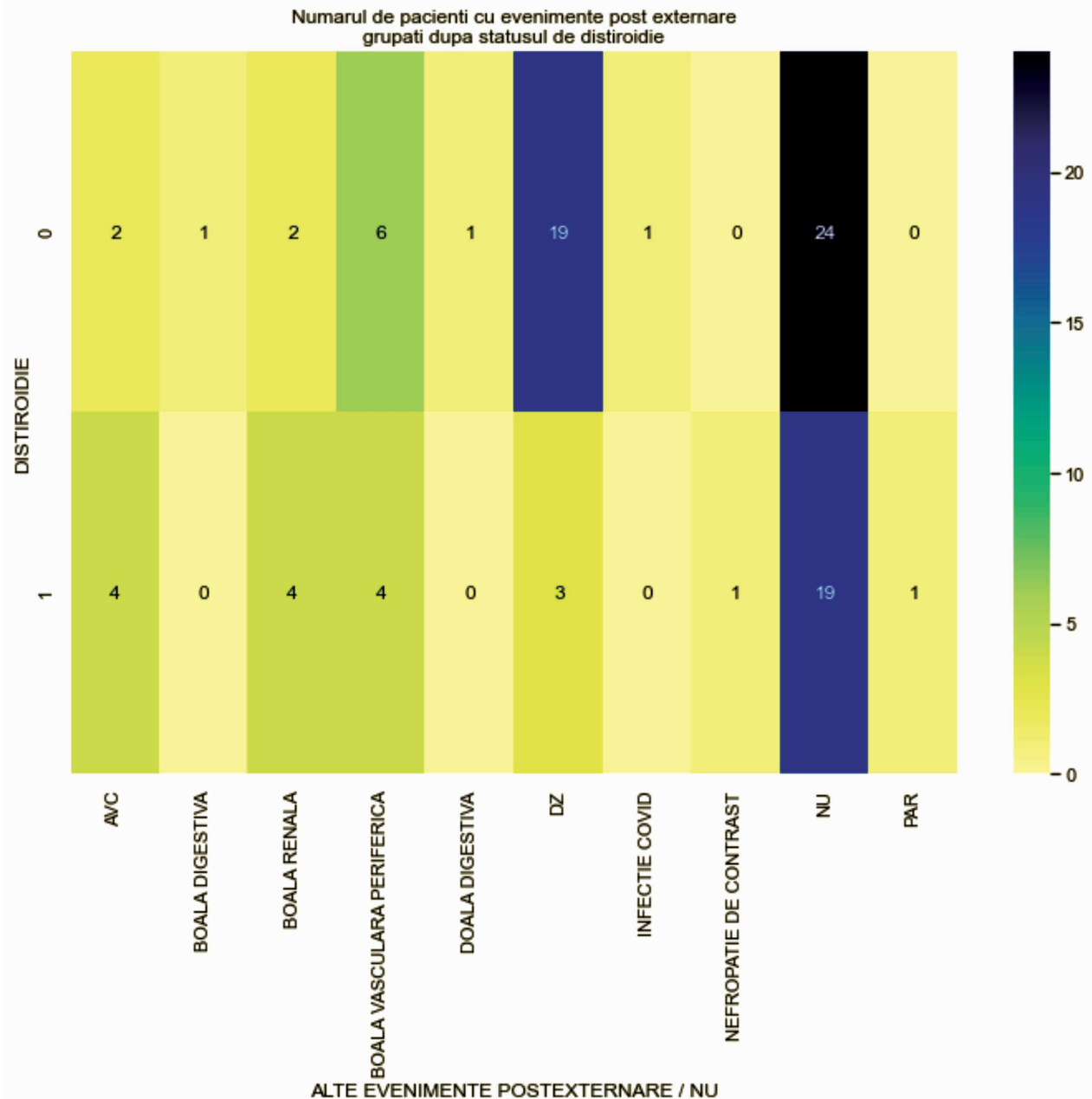

FIGURA 3. Evenimente postexternare

$(p<|z|<0,05$ înseamnă că avem 95\% motive să credem că există o legătură reală între reinternare și acea variabilă) (figura 4).

Prin urmare, prezenta evenimentelor cardiace duce la o probabilitate de reinternare de $83 \%$. Afectarea coronariană trivasculară determină o probabilitate de reinternare de $67 \%$. Prezența distiroidiei determină o probabilitate de reinternare de doar $29 \%$. Creșterea presiunii diastolice peste $80 \mathrm{mmHg}$ determină o probabilitate de reinternare de $55 \%$. În urma analizei, creșterea proteinei $\mathrm{C}$ reactive $\mathrm{cu}$ o unitate, crește probabilitatea de reinternare la $32 \%$ (figura 5 ).
Având în vedere eșantionul redus, de 100 de pacienți, dintre care 7 (7\%) pacienți cu statusul decedat, nu se poate analiza foarte exact influența factorilor care duc la mortalitate. $\mathrm{O}$ anumită legătură este prezentată în matricea de corelație, însă ar trebui măsurate pe un eșantion mai mare. Totuși, s-a folosit și tehnologia regresie logistică pentru a avea măcar anumite indicii despre câțiva factori care chiar ar putea avea un impact. S-au analizat factorii următori: insuficienta cardiacă la prezentare (cuantificată prin valoarea NTproBNP > $125 \mathrm{pg} / \mathrm{ml}$ ) și nivelul crescut al troponinei I înalt sensibilă, $p=0,008$; disfuncția sistolică severă de

TABEL 1. Predictorii și probabilitatea de reinternare a pacientului cu sindrom coronarian acut și distiroidie

\begin{tabular}{|l|c|c|c|c|c|}
\hline \multicolumn{1}{|c|}{ Variabila } & $\begin{array}{c}\mathbf{p}<|\mathbf{z}| \\
\text { variabila }\end{array}$ & $\begin{array}{c}\text { Coeficient } \\
\text { intercept }\end{array}$ & $\begin{array}{c}\text { Contribuţie la } \\
\text { scor, estimatorul } \\
\text { beta }\end{array}$ & $\begin{array}{c}\text { Probabilitate } \\
\text { când variabila } \\
\text { este 0 }\end{array}$ & $\begin{array}{c}\text { Probabilitate } \\
\text { când variabila } \\
\text { este 1 }\end{array}$ \\
\hline EVENIMENTE_CARDIACE_NU & 0 & 1,609 & -3.769 & $83 \%$ & $10 \%$ \\
\hline AFECTARE_CORONARIANA_TRI & 0,01 & $-0,65$ & 1,348 & $34 \%$ & $67 \%$ \\
\hline DISTIROIDIA & 0,04 & $-0,032$ & $-0,901$ & $49 \%$ & $28 \%$ \\
\hline PRESIUNE_DIASTOLICA_over80 & 0,025 & $-0,742$ & 0,953 & $32 \%$ & $55 \%$ \\
\hline CRP & 0,017 & $-1,03$ & 0,26 & $26 \%$ & $32 \%$ \\
\hline
\end{tabular}




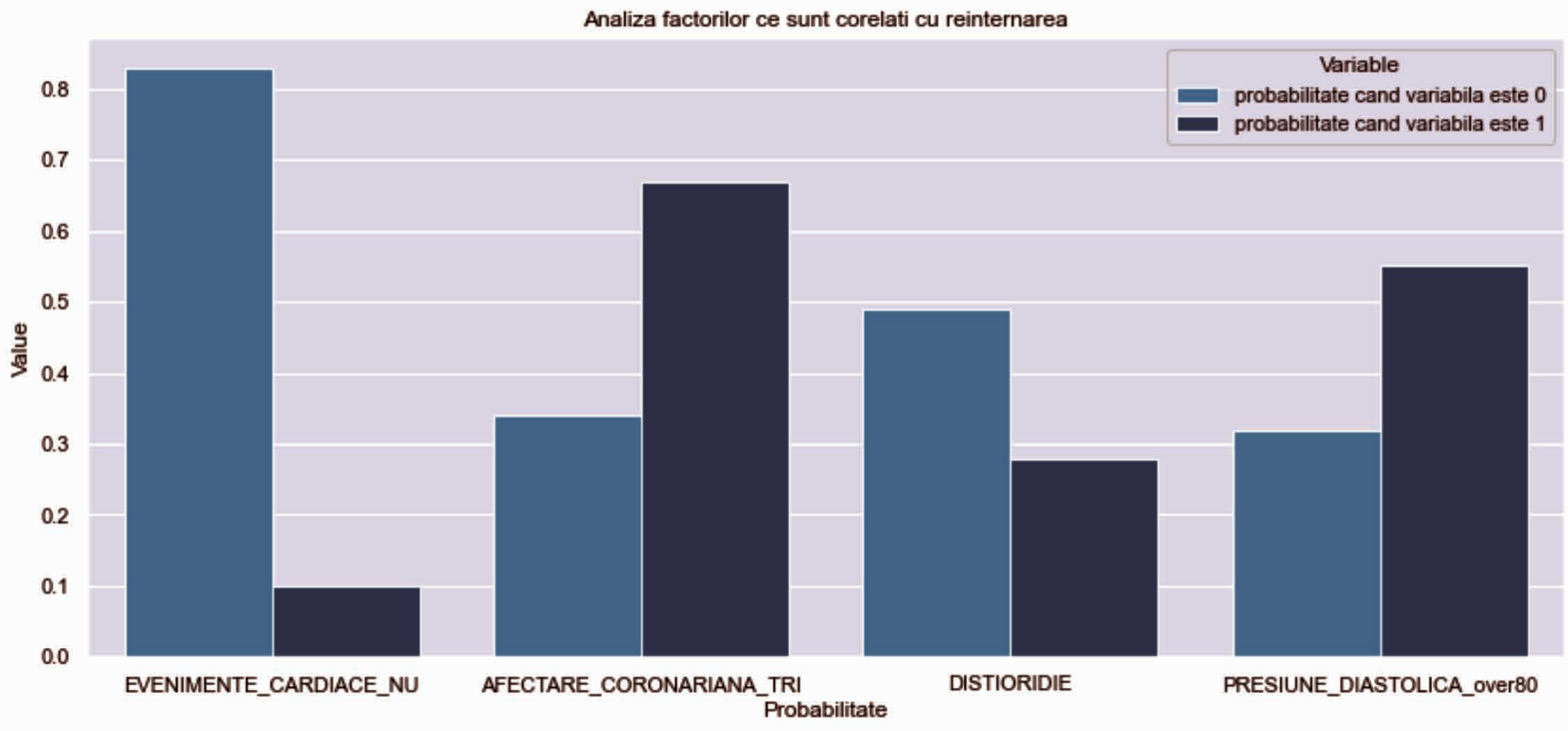

FIGURA 4. Factorii corelați cu reinternarea pacientului cu sindrom coronarian acut și distiroidie

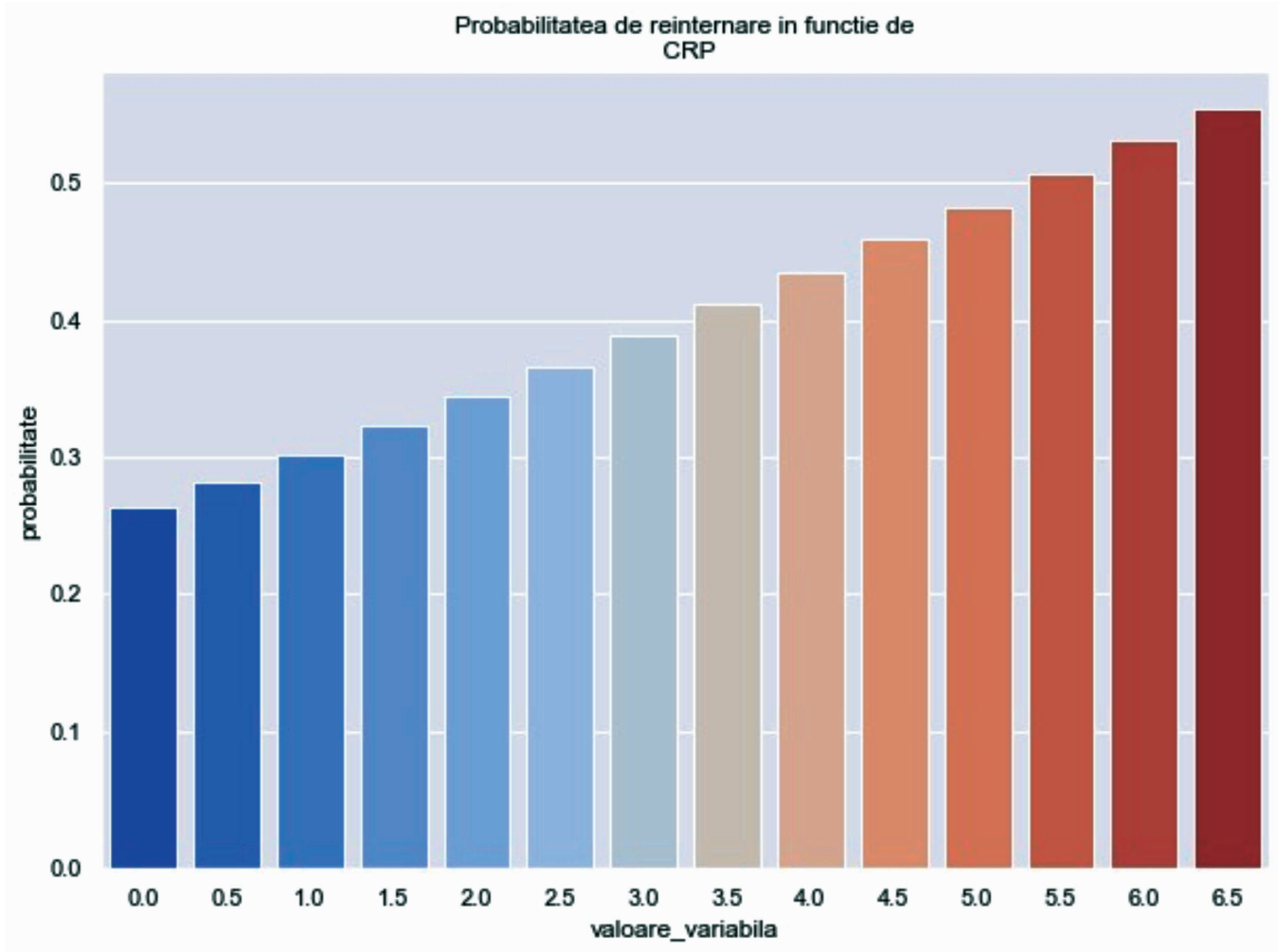

FIGURA 5. Probabilitatea de reinternare în funcție de valoarea proteinei C reactive

ventricul stâng, calculată ca FEVS(\%) < 30, În acest sens, avem motive să credem, cu 95\% încredere că există o legătură între disfuncția sistolică severă de ventricul stâng și mortalitate $(p=0,006)$.

Calculând probabilitatea de deces la pacienții cu disfuncție sistolică severă de ventricul stâng, cuantificată prin $\mathrm{FEVS}<30 \%$, și distiroidie folosind formula $p=\mathrm{e}^{\text {scor }} /\left(1+\mathrm{e}^{\text {scor }}\right)$, cu scor $=-2,9124+3,6055 * *$ FEVS severă $=0,6931$, am obținut un $p$ de 0,66 , ce determină o valoare predictivă de deces de $66 \%$ în prezența distiroidiei, comparativ cu 5\% în absența distiroidiei.

\section{DISCUTुII}

Manifestarea clinică a sindromului coronarian acut este diferită în cele două grupe de pacienți cu distiroidie: angina instabilă pentru pacienții cu hipertiroidism și infarct miocardic acut fără supradenivelare de seg- 
ment ST pentru pacienții cu hipotiroidism. Un rezultat asemănător este obținut de Mukherjee și colab., într-un studiu efectuat în 2018 (6). Deși există mai multe studii cu privire la acest subiect, cele mai multe dintre ele nu au puterea de a oferi un răspuns dacă modificările TSH au o relație de cauzalitate sau doar un răspuns nespecific la stresul bolii (5).

În studiul nostru, s-a evidențiat că pacienții cu sindrom coronarian acut și cu niveluri modificate de hormoni tiroidieni au avut un risc de mortalitate de aproape două ori mai mare comparativ cu pacienții cu sindrom coronarian acut și eutiroidie. Aceste rezultate susțin datele anterioare din literatură, care demonstrează creșterea mortalității pe termen lung la pacienții cu nivel scăzut de hormoni tiroidieni cu boli cardiovasculare (7). Într-o analiză anterioară în literatura de specialitate, disfuncția tiroidiană diagnosticată cu niveluri de TSH mai mari decât intervalul de referință, a fost asociat cu o mortalitate crescută (8).

În studiul nostru, prezența distiroidiei la pacientul cu sindrom coronarian acut are un rol protector în dezvoltarea diabetului zaharat în primii 5 ani $(p=0,025)$. Literatura științifică medicală nu a studiat în mod deosebit această corelație, motiv pentru care putem considera că rezultatele noastre ar putea constitui baza unui studiu viitor care să înroleze un număr mai mare de pacienți pentru o mai bună veridicitate statistică.

Proteina $C$ reactivă, sensibil marker inflamator nespecific, ce prezice în diverse studii clinice, evenimente vasculare precum infarctul miocardic, accidentul vascular cerebral $(9,10)$, precum și dezvoltarea diabetului la subiecții sănătoși (11), în studiul nostru, la pacienții cu sindroame coronariene acute, este factor predictor pentru reinternarea acestor pacienți.

În urma studiului a reieșit că distiroidia influențează, dar nu cu valoare semnificativ statistică, gravitatea leziunilor coronariene, respectiv scorul SYNTAX (scor cu punctaj mai mare în prezența distiroidiei). În literatura de specialitate, Cho și colab. au arătat că scorul SYNTAX este corelat cu evoluția pe termen lung, cu evenimente de moarte subită, accident vascular sau infarct miocardic, pentru leziunile coronare complexe (12).

Rata de deces în lotul pacienților eutiroidieni este de 5\% (3 pacienți), pe când în lotul de pacienți cu distiroidie rata de deces este de $9 \%$ (4 pacienți). În concordanță cu literatura de specialitate, reprezentată printr-un studiu realizat în 2019, în care Yang și colab. au evidențiat că atât hipotiroidismul subclinic, cât și hipertiroidismul subclinic sunt asociate cu prognosticul nefaforabil la pacienții cu insuficiență cardiacă (13), în studiul nostru, prezența disfuncției sistolice severe a ventricului stâng determină o probabilitate de deces de $66 \%$. Nu s-a înregistrat niciun deces în lotul pacienților internați cu infarct miocardic acut cu supradenivelare de segment ST.

Punctele forte ale studiului le reprezintă determinarea gravității leziunilor coronariene și factorii predictivi valoare statistică pentru reinternare și pentru mortalitate la pacientul cu sindrom coronarian acut și afectare tiroidiană.

Limita studiului o reprezintă faptul că loturile de pacienți nu au fost suficient de numeroase astfel încât nu am putut oferi puterea statistică scontată pentru unele variabile luate în discutie (de exemplu creatinina serică, sodiul, potasiul seric). În plus, nu am măsurat nivelurile altor hormoni tiroidieni. Extinderea studiului cu determinarea nivelului de T3 și FT3, ATPO ar aduce date în plus.

\section{CONCLUZII}

În urma studiului efectuat, s-a concluzionat că prezența distiroidiei la internare, indiferent de tipul acesteia, hipotiroidie sau hipertiroidie, este protectoare pentru apariția diabetului zaharat în evoluție.

Factorii contributori la reinternarea pacienților cu sindrom coronarian acut în studiul mai sus prezentat au fost identificați ca fiind: absența distiroidiei, afectarea vasculară tricoronariană, prezența valorilor crescute a proteinei $\mathrm{C}$ reactive, precum și tensiunea arterială diastolică și a tensiunea arterială medie crescute.

Determinarea de rutină a nivelurilor plasmatice ale hormonilor tiroideni la pacienții care suferă de sindrom coronarian acut ar putea dezvălui un marker prognostic silențios, în ciuda faptului că momentul exact al modificărilor hormonale nu este încă clar definit.

Pentru a crește cunoștințele actuale cu privire la valoarea prognostică și la contribuția distiroidiei la apariția și respectiv la agravarea bolilor cardiovasculare, pentru confirmarea cu exactitate a efectelor interrelației tiroidă-cord, atât pe termen scurt, cât și pe termen lung, este nevoie de studii clinice concepute special, în clinica noastră de cardiologie existând posibilitatea de a continua acest studiu în cel puțin două direcții: prin înrolarea de noi pacienți și, respectiv, prin urmărirea pacienților înrolați pe termen mediu și lung pentru a evalua regresia leziunilor coronariene și ameliorarea parametrilor biochimici sub tratament (substitutiv hormonal sau antitiroidiene de sinteză). 


\section{REFERENCES}

1. Chattergoon NN. Thyroid hormone signaling and consequences for cardiac development. J Endocrinol. 2019 Jul 1;242(1):T145-T160.

2. Arambam P, Kaul U, Ranjan P, Janardhanan R. Prognostic implications of thyroid hormone alterations in acute coronary syndrome-A systematic review. Indian Heart J. 2021 Mar-Apr;73(2):143-148.

3. Jabbar A, Pingitore A, Pearce SH, Zaman A, lervasi G, Razvi S. Thyroid hormones and cardiovascular disease. Nat Rev Cardiol. 2017 Jan;14(1):39-55.

4. Auer J, Berent R, Weber T, Lassnig E, Eber B. Thyroid function is associated with presence and severity of coronary atherosclerosis. Clin Cardiol. 2003 Dec;26(12):569-73.

5. Economidou F, Douka E, Tzanela M, Nanas $S$, Kotanidou A. Thyroid function during critical illness. Hormones (Athens). 2011 Apr-Jun;10(2):117-24.
6. Mukherjee S, Datta S, Mandal SC. Prevalence of Subclinical Hypothyroidism in Acute Coronary Syndrome in Nondiabetics: Detailed Analysis from Consecutive 1100 Patients from Eastern India. J Thyroid Res. 2018 Sep 4;2018:9030185.

7. Yang $\mathrm{H}$, Zhang $\mathrm{L}, \mathrm{Xu} \mathrm{CH}$. Use of the SYNTAX Score II to predict mortality in interventional cardiology: A systematic review and meta-analysis. Medicine (Baltimore). 2019 Jan;98(2):e14043.

8. Chaker L, van den Berg ME, Niemeijer MN, Franco OH, Dehghan A, Hofman A, Rijnbeek PR, Deckers JW, Eijgelsheim M, Stricker BH, Peeters RP. Thyroid Function and Sudden Cardiac Death: A Prospective Population-Based Cohort Study. Circulation. 2016 Sep 6;134(10):713-22.

9. Black S, Kushner I, Samols D. C-reactive Protein. J Biol Chem. 2004 Nov 19;279(47):48487-90.
10. Hirschfield GM, Pepys MB. C-reactive protein and cardiovascular disease: new insights from an old molecule. QJM. 2003 Nov;96(11):793-807.

11. Pradhan AD, Manson JE, Rifai N, Buring JE, Ridker PM. C-reactive protein, interleukin 6, and risk of developing type 2 diabetes mellitus. JAMA. 2001 Jul 18;286(3):327-34.

12. Cho $Y$, Shimura $S$, Aki A, Furuya $H$, Okada $\mathrm{K}$, Ueda T. The SYNTAX score is correlated with long-term outcomes of coronary artery bypass grafting for complex coronary artery lesions. Interact Cardiovasc Thorac Surg. $2016 \mathrm{Jul} ; 23(1): 125-32$.

13. Yang G, Wang Y, Ma A, Wang T. Subclinical thyroid dysfunction is associated with adverse prognosis in heart failure patients with reduced ejection fraction. $B M C$ Cardiovasc Disord. 2019 Apr 4;19(1):83. 